\title{
Effect of Zinc and Iron Fortification on Growth and Yield of Summer Pearl Millet (Pennisetum glaucum (L.) R. Br. Emend. Stuntz)
}

\author{
R. P. Vaja ${ }^{1 *}$, H. M. Bhuva ${ }^{2}$, L. K. Mokariya ${ }^{1}$ and C. P. Jani ${ }^{1}$ \\ ${ }^{1}$ Department of Agronomy, ${ }^{2}$ Department of Agronomy, Pearl Millet Research Station, College \\ of Agriculture, Junagadh Agricultural University, Junagadh, Gujarat, India \\ *Corresponding author
}

\begin{tabular}{|l|}
\hline \multicolumn{1}{|l}{} \\
\hline Key w or d s \\
Growth, Iron, \\
Pearl millet, \\
Yield and Zinc
\end{tabular}

\section{A B S T R A C T}

\section{Introduction}

Pearl millet [Pennisetum glaucum (L.) R. Br. Emend. Stuntz] is the most widely grown type of millet. It has been grown in Africa and South Asia since prehistoric times. In Asia, important pearl millet growing countries are India, China, Nigeria, Pakistan, Sudan, Egypt, Arabia and Russia. Pearl millet belongs to Gramineae family. It is one of the most important food grain cereal crops of India and ranks fourth in area after rice, wheat and sorghum. It is one of the major cereal crop grown in the arid and semi-arid regions of the world. India is the largest single producer of the crop, both in terms of area 6.93 million
A field experiment was conducted on medium black calcareous clayey soil at Junagadh (Gujarat) during summer season of 2019 to study the effect of zinc and iron fortification on growth and yield of summer pearl millet (Pennisetum glaucum (L.) R. Br. Emend. Stuntz). The experimental results revealed that significantly higher values of growth parameters viz., Number of total tillers/plan tand yield attributes viz., Number of effective tillers/plant, Ear head length, Ear head girth and 1000-grain weight along with higher seed yield and stover yield were recorded with increasing foliar spray of iron and zinc. However, higher net return and $\mathrm{B}: \mathrm{C}$ ratio were also realized with the application of $\mathrm{FeSO}_{4} @ 1.0 \% 25$ $\& 50 \mathrm{DAS}$ and $\mathrm{ZnSO}_{4} @ 0.5 \%$ at 25 \& $50 \mathrm{DAS}$.

hectares and production 8.61 million tonnes and productivity of $1243 \mathrm{~kg} / \mathrm{ha}$ (Directorate of Millets Development, 2020) during summer season.

Major pearl millet growing states in India are Rajasthan (52.34\%), Maharashtra (14.6\%) and Gujarat (9.9\%). Banaskatha, Junagadh, Jamnagar, Rajkot, Mehsana, Kheda, Amerali and Kutch are the major pearl millet growing districts of Gujarat. The area under summer pearl millet was 2.26 lakh hectares with an annual production of 6.17 lakh tonnes and productivity of $2721 \mathrm{~kg} / \mathrm{ha}$ in Gujarat state during 2019-2020 (Anon., 2020). 
Zinc plays significant role in various enzymatic and physiological activities of plant. Zinc is an essential micro nutrient required for growth and development of the higher plants (Kochian, 1993 and Marschner, 1995) and is involved in membrane integrity, enzyme activation and gene expression (Kim et al., 2002).

Iron plays a role in the formation of plant chlorophyll. Iron-containing plant haemoglobins are another promising target for altering Fe content in plant-based foods. Plant haemoglobin is similar to the human haemoglobin, with Fe binding capacity and is most commonly found in nodulating legumes (nitrogen fixing plants) (Kundu et al., 2003).

Bio fortification is the process by which the nutritional quality of food crops is improved through agronomic practices, conventional plant breeding or modern biotechnology. Bio fortification differs from conventional fortification in that bio fortification aims to increase nutrient levels in crops during plant growth rather than through manual means during processing of the crops. Agronomic approaches such as application of $\mathrm{Zn}$ and Fecontaining fertilizers appear to be rapid and simple solution to address the $\mathrm{Zn}$ and $\mathrm{Fe}$ deficiency in crop and human health. Agronomic fortification with foliar application of micronutrients particularly zinc and iron not only increase the yield but also nutrient quality of pearl millet for obtaining good economic return and also nutritional security. So, enrichment of pearl millet with zinc and iron fortification is one of the option to improve the quality.

\section{Materials and Methods}

The field experiment was conducted during the year 2019 at Instructional Farm, Department of Agronomy, Junagadh Agricultural University, Junagadh (Gujarat), which is situated in South Saurashtra Agroclimatic region of Gujarat state and enjoys a typically subtropical climate characterized by fairly cold and dry winter, hot and dry summer as well as warm and moderately humid monsoon. Which is situated at $21.5^{\circ} \mathrm{N}$ latitude and $70.5^{\circ} \mathrm{E}$ longitudes with an altitude of $60 \mathrm{~m}$ above the mean sea level. The soil was clayey in texture and slightly alkaline in reaction with $\mathrm{pH} 7.9$ and EC 0.33 $\mathrm{dS} / \mathrm{m}$. The soil of the experimental site was medium in available nitrogen $(277 \mathrm{~kg} / \mathrm{ha})$, available phosphorus $(27.02 \mathrm{~kg} / \mathrm{ha})$, available potassium $(279.55 \mathrm{~kg} / \mathrm{ha})$, medium in available zinc $(0.65 \mathrm{ppm})$ and medium in available iron (5.53 ppm). The soil was free from any kind of salinity or sodicity hazards.

The experiment was conducted with three foliar spray of $\mathrm{FeSO}_{4}$ viz., $\mathrm{F}_{1}$ : Control (No spray), $\mathrm{F}_{2}: \mathrm{FeSO}_{4} @ 1.0 \%$ at $25 \mathrm{DAS}, \mathrm{F}_{3}$ : $\mathrm{FeSO}_{4} @ 1.0 \%$ at $25 \& 50$ DAS and Foliar spray of $\mathrm{ZnSO}_{4} v i z ., \mathrm{Z}_{1}$ : Control (No spray), $\mathrm{Z}_{2}: \mathrm{ZnSO}_{4} @ 0.5 \%$ at $25 \mathrm{DAS}, \mathrm{Z}_{3}: \mathrm{ZnSO}_{4}$ @ $0.5 \%$ at $25 \& 50$ DAS in factorial randomized block design replicated three times. The crop was sown at $45 \times 10 \mathrm{~cm}^{2}$ spacing on $20^{\text {th }}$ February and recommended dose of fertilizer was $120-60-0$ N-P-K kg/ha and all other recommended practices were adopted according to as per needed of crop requirement. The crop was harvested at physiological maturity on May 17, 2019. The growth and yield attributes were recorded from the five tagged plants in each plot. Seed and stover yield were recorded from the net plot area and converted into kilogram per hectare base.

The expenses incurred for all the cultivation operations from preparatory tillage to harvesting including the cost of inputs viz., seeds, manures, fertilizers, irrigation, etc. applied to each treatment was calculated on the basis of prevailing local charges. The gross realization in terms of rupees per 
hectare was worked out taking into consideration the seed and stover yields from each treatment and local market prices. Net return of each treatment was calculated by deducting the total cost of cultivation from the gross returns. The benefit:cost ratio $(\mathrm{B}: \mathrm{C})$ was calculated by dividing gross return with cost of cultivation.

Statistical analysis of the individual data of various characters studied in the experiment was carried out using standard statistical procedures as described by Panse and Sukhatme (1985). Standard error of mean, critical difference (C.D.) at 5 per cent level of probability and coefficient of variance were worked out for the interpretation of the results.

\section{Results and Discussion}

\section{Effect of iron}

It is apparent from data in Table 1 indicated that the increasing foliar spray of iron significantly increased the number of total tillers per plant as well as number of effective tillers per plant, earhead length, earhead girth and 1000-grain weight. Seed and stover yields also increased significantly up to $\mathrm{FeSO}_{4}$ @ $1.0 \%$ at $25 \& 50$ DAS. Application of $\mathrm{FeSO}_{4}$ @ $1.0 \%$ at $25 \& 50$ DAS registering highest grain yield (4430 kg/ha) and stover yield (8019 kg/ha). This might be due to iron role in starch formation and protein synthesis as well as maintenance and synthesis of chlorophyll in plants.

Table.1 Growth attributes, yield attributes and yield as influenced by different iron and zinc applications

\begin{tabular}{|l|c|c|c|c|c|c|c|}
\hline \multicolumn{1}{|c|}{ Treatments } & $\begin{array}{c}\text { Number of } \\
\text { total } \\
\text { tillers/plant }\end{array}$ & $\begin{array}{c}\text { Number of } \\
\text { effective } \\
\text { tillers/plant }\end{array}$ & $\begin{array}{c}\text { Earhead } \\
\text { Length } \\
\text { (cm) }\end{array}$ & $\begin{array}{c}\text { Earhead } \\
\text { Girth } \\
\text { (cm) }\end{array}$ & $\begin{array}{c}\text { 1000-grain } \\
\text { weight }\end{array}$ & $\begin{array}{c}\text { Seed } \\
\text { yield }\end{array}$ & $\begin{array}{c}\text { Stover } \\
\text { yield } \\
\text { (kg/ha) }\end{array}$ \\
(kg/ha) \\
\hline Foliar spray of iron
\end{tabular}

$\mathrm{RDF}\left(120: 60: 00 \mathrm{~kg} \mathrm{~N}: \mathrm{P}_{2} \mathrm{O}_{5}: \mathrm{K}_{2} \mathrm{O} / \mathrm{ha}\right)$ was applied to all the treatments 
Table.2 Economics of pearl millet as influenced by different iron and zinc applications

\begin{tabular}{|c|c|c|c|c|}
\hline Treatments & $\begin{array}{l}\text { Gross } \\
\text { return } \\
\text { (₹/ha) }\end{array}$ & $\begin{array}{l}\text { Cost of } \\
\text { cultivation } \\
\text { (₹ /ha) }\end{array}$ & $\begin{array}{l}\text { Net return } \\
\text { (₹ /ha) }\end{array}$ & $\begin{array}{l}\text { B:C } \\
\text { ratio }\end{array}$ \\
\hline \multicolumn{5}{|l|}{ Foliar spray of iron } \\
\hline$F_{1}:$ Control (No spray) & 80348 & 26134 & 54214 & 3.07 \\
\hline $\mathrm{F}_{2}: \mathrm{FeSO}_{4} @ 1.0 \%$ at $25 \mathrm{DAS}$ & 87137 & 27158 & 59979 & 3.20 \\
\hline $\mathrm{F}_{3}: \mathrm{FeSO}_{4} @ 1.0 \%$ at $25 \& 50 \mathrm{DAS}$ & 95786 & 28183 & 67603 & 3.40 \\
\hline \multicolumn{5}{|l|}{ Foliar spray of zinc } \\
\hline $\mathrm{Z}_{1}$ : Control (No spray) & 79237 & 26347 & 52890 & 3.00 \\
\hline $\mathrm{Z}_{2}: \mathrm{ZnSO}_{4} @ 0.5 \%$ at $25 \mathrm{DAS}$ & 87548 & 27158 & 60390 & 3.22 \\
\hline $\mathrm{Z}_{3}: \mathrm{ZnSO}_{4} @ 0.5 \%$ at $25 \& 50 \mathrm{DAS}$ & 96486 & 27969 & 68517 & 3.45 \\
\hline
\end{tabular}

The increased in the availability of iron to plant might have stimulated the metabolic and enzymatic activities thereby increasing the growth of the crop. Similar findings were also reported by Yadav et al., (2013). Iron provides potential for many of the enzymatic transformations. Several of these enzymes are involved in chlorophyll synthesis, grain formation and dry matter production, which ultimately lead to final yield characters such as number of effective tillers per plant. These findings are in confirmation to the earlier reported by Gupta et al., (2002) and Abbas et al., (2009). There was considerable increase in net return and $\mathrm{B}: \mathrm{C}$ ratio due to iron application. Increasing foliar spray of iron significantly increased the net returns up to $\mathrm{FeSO}_{4} @ 1.0 \%$ at 25 \& 50 DAS (₹ 67603/ha) with $\mathrm{B}: \mathrm{C}$ ratio 3.40 . This might be due to significant increase in yield with increased supply of available iron and correction in hidden deficiency of iron in plant or better nutrition of the crop with the foliar application of this nutrient. It gave maximum recovery from application of iron with less expenditure. Similar result was also reported by Yadav et al., (2013).

\section{Effect of zinc}

The perusal of data presented in Table 1 revealed that the increasing foliar spray of zinc significantly increased the number of total tillers per plant as well as number of effective tillers per plant, earhead length, earhead girth and 1000-grain weight. Seed and stover yields are increased significantly up to $\mathrm{ZnSO}_{4} @ 0.5 \%$ at $25 \& 50$ DAS. Application of $\mathrm{ZnSO}_{4} @ 0.5 \%$ at $25 \& 50$ DAS registering highest grain yield (4462 $\mathrm{kg} / \mathrm{ha}$ ) and stover yield (8084 kg/ha). Zn plays important role in synthesis of various enzymes like carbonic anhydrase, glutamic acid dehydrogenase, lactic acid dehydrogenase and some peptidases. It is also considered to be precursor for auxin synthesis involved in nitrogen metabolism and several oxidation-reduction reactions, stability of RNA and starch formation thus its adequate supply results higher dry matter production, ultimately growth and development of plants (Dadhich and Gupta, 2003). Parallel results were also established by Abbas et al., (2016). The increased in the yield attributes might also be due to role of zinc in biosynthesis of indole acetic acid (IAA) and especially due to its role in initiation of primordia for reproductive parts and partitioning of photosynthates towards them (Wear and Hagler, 1968), which might have been resulted in better flowering and fruiting. This finding is in conformation to the earlier reports of Singaravel et al., (2001). 
Successive increase in zinc rates up to $0.5 \%$ at $25 \& 50$ DAS significantly increased net returns (₹ 68517/ha) and B:C ratio 3.45. This could be primarily due to higher grain and stover yields (Table 2) with comparatively less additional cost of zinc compared to additional yield under this treatment. The result is in conformity with the work of Gill and Walia (2013)

On the basis of the results of the present one year field study, it can be concluded that higher production and net returns from summer pearl millet (GHB-732) can be secured by application of $\mathrm{FeSO}_{4} @ 1.0 \%$ and $\mathrm{ZnSO}_{4} @ 0.5 \%$ at $25 \& 50 \mathrm{DAS}$.

\section{Acknowledgments}

The authors are grateful to the Director, College of Agriculture, Junagadh Agricultural University for providing necessary field and laboratory facilities during M.Sc. research work.

\section{References}

Abbas, A., Safdar, M. E., Ali, A., Asif, M. and Rehman, A. 2016. Effect of foliar application of zinc at different growth stages on grain yield and quality of wheat (Triticum aestivum L.). J. Environ. Agric., 1(2): 106-11.

Abbas, G., Khan, M. Q., Khan, M. J., Hussain, F. and Hussain, I. 2009. Effect of iron on the growth and yield contributing parameters of wheat (Triticum aestivum L.). The Journal of Animal \& Plant Sciences, 19(3): 135139.

Anonymous, 2020. District wise area, production, yields of major crops of Gujarat State. Published by Directorate of Agriculture, Government of Gujarat, Gandhinagar.

Dadhich, L. K and Gupta, A. K. 2003.
Productivity and economics of pearl millet fodder as influenced by sulphur, zinc and planting pattern. Forage Research, 28(4): 207-209.

Directorate of millets development, 2020. Project Coordinated Review. pp-1.

Gill, J. S. and Walia, S. S. 2013. Effect of foliar application of iron, zinc and manganese on direct seeded aromatic rice (Oryza sativa). Indian Journal of Agronomy, 59(1): 80-85.

Gupta, P. K., Sharma, N. N., Acharaya, H. K., Gupta, S. K. and Mali, G. S. 2002. Response of mungbean to zinc and iron on Vertisols of South-Western Plains of Rajasthan. National Symposium on Arid Legumes for Food Security and Promotion Trade, October, 2002. Sponsored by Indian Arid Legumes Society, CAZRI, Jodhpur.

Kim, T., Harry, A. M. and hazel, Y. W. 2002. Studies on the effect of zinc supply on growth and nutrient uptake in pecan. Journal of Plant Nutrition, 25: 19872000.

Kochian, L. V. 1993. Zinc absorption from hydroponic solution by plan roots. Zinc in soils and plants. Kluwer Publishers, the Netherlands. pp. 45-57.

Kundu, S., Trent, J. T. and Hargrove, M. S. 2003. Plants, humans and hemoglobins. Trends in Plant Sci., 8: 387-393.

Marschner, H. 1995. Mineral Nutrition of Higher Plants (2nd edition). Academic Press, London.

Panse, K. Y. and Sukhatme, P. V. 1985. Statistics for Agricultural Workers, Pub. Indian Council of Agricultural Research, New Delhi.

Singaravel, R., Imayavaramban, Y., Dhanunathan, K. and Shanmughapriya, N. 2001. Response of sesame (Sesamum indicum) to manganese and zinc nutrition. J. Oilseeds Res., 18: 136-138.

Wear, J. I. and Hagler, T. B. 1968. Plant food 
review. Spring.

Yadav, G. S., Shivay, Y. S., Kumar, D. and Babu, S. 2013. Enhancing iron density and uptake in grain and straw of aerobic rice through mulching and rhizo-foliar fertilization of iron. African Journal of Agricultural Research, $8(\mathrm{xx}): 5447-5454$.

\section{How to cite this article:}

Vaja, R. P., H. M. Bhuva, L. K. Mokariya and Jani, C. P. 2020. Effect of Zinc and Iron Fortification on Growth and Yield of Summer Pearl Millet (Pennisetum glaucum (L.) R. Br. Emend. Stuntz). Int.J.Curr.Microbiol.App.Sci. 9(10): 2699-2704.

doi: https://doi.org/10.20546/ijcmas.2020.910.326 